\title{
Financial Literacy as one of the Professional Competencies of Social Workers to Prevent or Solve Socio-economic Problems
}

\section{J. Pavelkova (Jaroslava Pavelkova)}

${ }^{1}$ Department of Health Care Sciences, Faculty of Humanities, Tomas Bata

University in Zlin, Czech Republic.

\section{E-mail address:}

jpavelkova@utb.cz

\section{Reviewers:}

Claus Muss

IGAP Zurich $\mathrm{CH}$

Jarmila Holkova

Malindi

\section{Reprint address:}

Jaroslava Pavelkova

Tomas Bata University in Zlin

Faculty of Humanities, Department of Health Care Sciences

Stefanikova 5670

76001 Zlin

Czech Republic

Source: Clinical Social Work and Health Intervention

Pages: $69-74$

Volume: 12

Issue: 1

\section{Publisher:}

International Society of Applied Preventive Medicine i-gap

\section{Keywords:}

Social work. Social worker. Client. Financial Literacy. Professional Competence. Socio-economic Problem.

CSWHI 2021; 12(1): 69 - 74; DOI: 10.22359/cswhi_12_1_14 (C) Clinical Social Work and Health Intervention

\section{Abstract:}

This paper deals with the issue of financial literacy as one of the professional competencies of social workers to prevent or solve socio-economic problems of clients. A practical example is presented of resolving the financial problems of a client of a non-profit social organization, a homeless shelter in the Czech Republic. Through knowledge and experience in financial literacy issues, the educated social worker is able to determine the extent and causes of material need persuade the client to cooperate, as well as mobilize him toward alleviating or eliminating his unfavorable financial situation. 


\section{Introduction}

Despite the many cautions given to the whole of today's society, more and more individuals find themselves in an unfavorable socio-economic situation due to socio-economic problems they have caused themselves or have been unable to prevent. Low economic and financial literacy manifests itself without distinction among all target social groups with the exception of young children. Typically, financial problems are caused by, e.g.: the loss of a job; imprisonment; breakdown of a marriage; loss of a partner; death of a family member; loss of housing; as well as the aforementioned low financial literacy. Frivolous decisions to purchase uncertified financial products from banks or non-banking institutions can bring an individual into debt, which may in turn cause him and his family, and thus the overall community, to fall into a state of poverty. Within various social service institutions, social workers regularly face problems in their activities with clients whom they attempt to address by helping individuals; families as well as communities develop socio-economic competences regarding financial management.

\section{The current situation in the Czech Republic regarding mortgage foreclosures}

The financial literacy of the Czech population remains unsatisfactory. Ten\% of Czech citizens face debt-related problems. Although the number of seizures is decreasing, the number is still huge. According to the Chamber of Executors in 2018, about 770,000 people were involved, with the total number of foreclosures at 4.54 million (Biben 2019). Based on information from Haba's Map of Seizures in 2017, 9.7\% of Czechs, i.e. 863,000 , had been a party to one or more foreclosures. Compared to 2016, this number has increased by more than 29,000 , with 493,000 people having been involved in 3 or more of these procedures. 151,000 people had participated in more than 10 foreclosures at this time (for a total of 4.67 million procedures in all). Last year for the first time, more mortgages were ended in the Czech Republic then were begun. Executors launched more than half a million new mortgages in 2018, but closed 35,000 more. On the other hand, the number of newly launched seizures in 2018 has fallen year by year by 106,000 , to
505,000 , and the figure has been decreasing for several years in a row. The number of completed foreclosures has been growing for a long time, with 540,000 last year (Biben, 2019). As reported by Mecirova (2018), the largest increase in foreclosures was recorded in the regions of Karlovy Vary $(10.2 \%)$, Usti nad Labem (8.8\%) and Central Bohemia (5.5\%), while the absolute worst situations could be found for the inhabitants in the cities of Usti nad Labem (21.9\%) and Most $(21.0 \%)$. The negative development of over-indebtedness in these regions was influenced mainly by debt cycling to pay off a standing debt. The average age of a Czech borrower is 44 years, but despite information interventions, every year the number of foreclosures against seniors in the Czech Republic has increased $(61,000$ persons aged 65+).

\section{Financial literacy}

Financial literacy is a collection of knowledge, skills, attitudes and values that a person needs to financially secure himself and his family in today's society and to actively engage in the market for financial products and services. A financially literate citizen focuses on money and price issues, and is able to responsibly manage a personal or family budget, including managing financial assets and financial liabilities in the face of changing life situations. As stated in the Financial Literacy Primer (2011), financial literacy is a special subsection of broader economic literacy which also includes, for example, the ability to secure income; to consider the implications of personal decisions for present and future income; orientation in the job market; the ability to make decisions regarding expenses; etc.

\section{Socio-economically disadvantaged groups}

A person's socio-economic portfolio often affects his position in society. In addition to other influences, economic disparities are determined by the fact that groups living in less favorable conditions have different approaches to education, quality of housing, meals, leisure, etc. Disadvantaged groups of the population consist of those that are challenged by debilities and disabilities which place them outside the normal life of society. The process by which an individual or an entire group of people is impeded or com- 
pletely denied access to resources, jobs and opportunities that enable participation in the social, economic and political activities of mainstream society (socio-economic decline) is termed social expulsion/social exclusion (Schavel et al. 2012). These groups include, e.g.: the long-term unemployed; unemployed young people; members of ethnic minorities and migrants; senior citizens; persons with disabilities or health conditions; persons with long-term or unmanageable debt; those with limited marketable skills; people for whom living on social benefits has become a way of life; persons with various kinds of addictions; children living in vulnerable families, i.e. with dysfunctional, poor, unemployed or multiple sets of parents; or in families with a history of violence (these children often receive a lower level of education, impaired health as well as fewer opportunities and incentives toward social development); persons living in disadvantaged areas with high unemployment, low quality housing, poor transport services, etc.; persons released from prison; as well as mothers on parental leave and single mothers.

The risk of social exclusion increases in an individual who accumulates the above-mentioned hindrances, such as the long-term unemployed with low qualifications living in a disadvantaged area. Financial problems with concomitant over-indebtedness accelerate their exclusion from the ordinary life of the society to its margins, with a return to normalcy quite difficult. Social exclusion threatens those groups of people who have a weakened bond to at least 1 of the 3 integrated integration levels of society (Matel et al. 2011).

\section{Socio-economic competences of social workers}

The concept of socio-economic competence includes financial literacy (i.e. monetary, information and budget literacy) as well as other soft skills (i.e. communication and presentation skills that lead to increased success in the labor market). The absence and importance of these soft competences is highlighted by Nova (2017), who points out how employment support services are not sufficiently linked to social services. The problem is the lack of one-on-one work with the client in terms of the individual being able to present himself and communicate adequately, as well as the low continuity regarding retraining for a particular job. All of these deficiencies can decrease the efficiency of the tools used by social workers to help their clients secure employment.

If a person falls into a debt trap, i.e. a situation in which the repayment of one or more loans is resolved by taking out an additional loan, or if a lien is taken out on his home or other vital assets, it becomes more advantageous for him to reduce his legal income from which the repayment is calculated to a minimum, and for him to move his activities into the black economy. Social workers in various institutions are experiencing increased demands in terms of social and specialized counseling in the area of economic problems (Pavelkova 2018). The current financial crisis has brought out an even greater need for financial education focusing on the practical skills associated with managing a personal or family budget which are a prerequisite for the financial security of individuals and families. Financial education aims to work responsibly in terms of both personal and family finances with the goal of preventing the indebtedness of citizens and households.

\section{Social work with clients in a difficult financial situation}

According to Schavel et al. (2012), financial instability in families is currently a widespread problem and is considered one of the most important factors regarding secondary crises in families. Issues include: the total cost of household expenses; the levels of education achieved; the age of the main breadwinner; along with a potential increase in the number of household members who are economically active and can support the economic stability of the family. In particular, the unemployment of a family member; the necessity of working for minimum wage; finding only precarious work; working abroad may cause economic instability, a condition which is associated with other problems such as family debt and the inability to handle money. These circumstances frequently occur within single-parent families or in families led by single mothers, dependent on their own income and/or state aid in the form of benefits and allowances. The cause of the problems may also lie with the debtor, i.e.:

purchasing too many unnecessary goods and services; the non-payment of rent or mandatory 
fees; but also. from fees related to transportation and commuting, etc. (Pavelkova 2018). Members of the family may also contribute to the problems by assuming their own heavy liabilities; incurring compounded debt; indulging in socio-pathological addictions; as well as through mental immaturity and the inability to take control of their own life.

Disadvantaged individuals and families suffering from socio-economic problems are often unable or unwilling to help themselves. In these cases, it is necessary to use the help of an educated social worker working within a state or non-state institution which is ready to contribute to the resolution of the unfavorable financial situation of the individual and his family. In general, the prevention of socio-economic instability can be characterized by ensuring compliance and consistency by means of (Pavelkova 2013):

- National statutory regulations and measures, e.g. inspecting the activities of commercial entities, etc.

- The acceptance of ethics and moral values regulated by legal norms and their interpretation by commercial entities in the society.

- Cooperation with the media in raising public awareness of these issues.

- Well-prepared teachers carrying out their important role (educational institutions).

- The educated social worker, who is of the greatest importance and who must possess a predetermined set of skills, abilities, knowledge as well as certain personal qualities. This professional should be an expert in the social work sector and be knowledgeable about financial literacy, thus can contribute to improving problematic situations, in this case in the area of financial instability issues (social counseling, not only at the basic level but also at an advanced expert level to address the client's needs which are potentially in conflict with society).

- Prevention, lifelong learning, spiritual and ecclesiastical activities.

In terms of content, the social counseling to be offered is aimed at determining the extent of the nature and causes of material need (Schavel, Olah 2010, p. 68-69). This means that in the initial phases of engagement with the client the social counselor first focuses on identifying the primary causes of debt (using the basic prevailing social counseling methods). Through the professional's knowledge and experience; by using communication skills; a social counselor must develop a collaborative relationship with the client and mobilize him towards cooperation in dealing with the client's adverse situation. In working with the client, the counselor ensures that relevant information is readily available including expert advice from specialists, e.g. psychologists, doctors, clergy, attorneys and financial advisors. The counselor offers suggestions for addressing, directing and supporting the client as well as helping locate possible resources to help effectively correct the client's socio-economic problems. As mentioned above, these steps consist mainly of content frameworks of counseling with a focus on reducing the existent debts of the family; teaching members to manage situations at the present time; avoiding the creation of new debts; creating optimal conditions to strengthen the social ties of family members; along with engaging all family members in upcoming changes and procedures for dealing with the unfavorable financial reality.

Certain mechanisms within the state social system can be used, i.e. networks of social entities which fall within local jurisdictions that allow the use of social loans; one-off social assistance; etc. At the level of state administration in the area of social affairs, benefits are available for immediate material need as well as in the form of state social support funding (e.g. for a child at pre-school and school age in the form of subsidies, school supplies, motivational allowances, etc.). It is also possible to elicit help from civic associations that specialize in these issues and are able to provide clients with longterm assistance that complements the support mechanisms of other entities; one example being the Citizens Advice Centers in the Czech Republic. 39 of these centers are currently in existence; in addition to offering free legal advice, these institutions also provide financial advice as well as engage in other related activities with those in need (Association of Citizens Advice, 2019).

\section{Example of financial consulting with a client residing in a homeless shelter}

The provision of social services is governed by the Standards of Quality of Social Services contained in addendum No. 2 to the Decree of the 
Ministry of Labor and Social Affairs, No. 505/2006 Coll., which is an implementation regulation to Act No. 108/2006 Coll., . One of the law's goals, such as is the case with shelters in the Czech Republic, is to operate a network of community services aimed, inter alia, at those socially excluded or otherwise disadvantaged or at risk. This group also explicitly includes homeless women. The target group of the facilities is women aged 18 and over in an unfavorable social situation associated with the loss of a home or housing that they are unable to resolve on their own. This negative social situation can include cases of: insecure or unsatisfactory housing; unemployment; relationship problems;, lack of resources for everyday life; the suppression of fundamental rights and freedoms, the return from imprisonment or other institutional care, as well as the lack of basic skills necessary for everyday life. Work with clients can be divided into several activities, each of which can, however, also intersect with and influence each other. In our case, it is essential, for example, to provide operational advice on carrying out administrative and legal procedures (e.g. requests for obtaining appropriate social benefits, loss of documents, etc.). But the primary function is to provide important consultation services including assistance in the resolution of specific client problems in the area of debt, foreclosures, insolvency, etc. Here again, the importance of basic knowledge of the educated social worker regarding the provisions of financial literacy information to clients again comes to the fore. The following is an example of the successful resolution of the unfavorable financial situation of a client living in a homeless shelter.

\section{Case analysis}

A 25-year-old client, S. L., came to the shelter when she was released from the psychiatric ward for treatment for substance addiction. During the time she was living on the streets, she had no insight into her financial situation because of her substance dependency, and her debts to various parties had compounded. In 2014, the client borrowed 5 books from the library that she did not return and which she later lost as she was living in a squat.

Her debt in late fees to the library began to increase, and when the court decided that she should pay the large sum of 12,000 CZK (468 EUR) to the library, the client began to seek advice from a social worker.

Together the client and the social worker contacted the library to ascertain all of the information regarding the client's debt. After hearing the client's story, the library's legal department considered the situation, and a solution was offered. In situations when a social worker and a client are able to demonstrate the circumstances of such a case, the library's legal department has the option of lowering the debt upon agreement with the library director, even if a court decision regarding the matter has already been rendered. With the help of a social worker, the client catalogued her social situation in writing, describing the time she lived homeless on the street and succumbed to addiction, and thus fell into a state during which she was unable to control her actions and behavior.

The client and the social worker provided evidence of the following:

- Confirmation of regular attendance at a counseling center that deals with treatment for addiction.

- Confirmation of attendance at a low-threshold treatment facility while she was living on the street.

- Confirmation from the Labor Office of the Czech Republic that she is receiving material need benefit payments, and in what amount.

- Confirmation of hospitalization in the psychiatric ward of a hospital.

- Discharge report from the psychiatric ward.

- Rental agreement contract with the shelter.

The client was interested in resolving her financial situation, i.e. the debt she had incurred. All the pertinent information was documented in writing and sent to the library's legal department with the help of a social worker. Within one week, the client received information that the debt had been reduced by 10,000 CZK, leaving the client only with the calculated debt for the purchase of the books and the court fee, which came to only 2,000 CZK (78 EUR). The client agreed with the library on a payment schedule in which each month, she was to pay at least 100 CZK (4 EUR) at any library branch. In cooperation with the social worker, the client's active approach to solving her economic and social situation was encouraged. 


\section{Conclusion}

Significant indebtedness and the consequent inability to repay debts along with the ensuing enforcement proceedings is affecting increasing numbers of people, with no target social group excluded. One possibility to resolve and prevent financial uncertainty in people in contemporary society is the use of professionally trained social workers, who on the basis of their socio-economic competences can determine the extent and causes of a client's material need; open up avenues of cooperation for the client; finally, mobilize the client's financial and other resources to mitigate the unfavorable financial situation and often eliminate it altogether.

\section{References}

1. ARTICLE IN AN ONLINE PERIODICAL (2019) The Association of Citizens Advice (2019) [online] [cit. 2019-06-18]. Available from: https://www.obcanskeporadny.cz/en/ (Czech).

2. ARTICLE IN AN ONLINE PERIODICAL (2019) BIBEN M (2019) Current Data for 2018: New executions have decreased, but it is still half a million per year. Aktualne. cz. [online] [cit. 2019-06-19]. Available from: https://zpravy.aktualne.cz/domaci/novychexekuci-loni-ubylo-stale-je-to-ale-pul-milionu-za rok/r 380083b440f011e98a200cc47ab 5f122/(Czech).

3. TEAM AUTHORS (2011) The Financial Literacy Primer. Prague. Cofet. 416 p. (Czech).

4. MATEL A et al. (2011) Applied Social Pathology in Social Work. Bratislava. College of Health and Social Work of St. Elizabeth. 267 p. (Slovak).

5. ARTICLE IN AN ONLINE PERIODICAL (2018) MECIROVA L (2018) The number of executions in the Czech Republic increased in 2018. Finance.cz [online] [cit. 2019-0618]. Available from: http://www.finance.cz/ 505009-exekuce-v-cesku-2018/(Czech).

6. NOVA M (2017) Poverty and Social Exclusion as a Social Problem. In: Vansac P, Barkasi D, Popovicova M, Editors. Community care in helping professions. Proceedings of International Conference; Warsawa: Wyższa Szkoła Finansów i Zarządzania w Warszawie. p. 174-178. (Czech).

7. PAVELKOVA J (2013) Social and Educa- tional Context of Financial Literacy. In: Socio-economic and Humanities Studies. ISSN 1804-6800. Vol. 3, No 1, p. 62-65. (Czech).

8. PAVELKOVA J (2018) Practical Using Social-economic Competencies of Social Workers to Eliminate the Socio-economic Problems of the Client. In: Suvada J, Gallova A, Editors. The role of health and social work in today's society. Proceedings of International Conference; Rimavské Janovce: Association for Social Development and Citizens Support Slovak Republic. p. 427-439. (Czech).

9. SCHAVEL M et al. (2012) Social Work with Families with Socio-economic Problems. In: Pavelkova J, Preuss K, Editors. Social and Educational Context of Financial Literacy. Prague: Banking Institute College. p. 43-50. (Slovak).

10. SCHAVEL M, OLAH M (2010) Social counselling and communication. Bratislava. College of Health and Social Work of St. Elizabeth. 218 p. (Slovak).

11. STANDARDS OF QUALITY OF SOCIAL SERVICES, ANNEX NO. 2 (2006) Of the Decree of the Ministry of Labor and Social Affairs of the Czech Republic, No. 505/2006 Coll., Implementing regulation to Act No. 108/2006 Coll., On Social Services. (Czech). 